University of Nebraska - Lincoln

DigitalCommons@University of Nebraska - Lincoln

Faculty Publications: Department of Entomology

Entomology, Department of

1990

\title{
Environmental Influences on Soil Macroarthropod Behavior in Agricultural Systems
}

\author{
Michael G. Villani \\ NYSAES/Cornell University \\ Robert J. Wright \\ University of Nebraska, rwright2@unl.edu
}

Follow this and additional works at: https://digitalcommons.unl.edu/entomologyfacpub

Part of the Entomology Commons

Villani, Michael G. and Wright, Robert J., "Environmental Influences on Soil Macroarthropod Behavior in Agricultural Systems" (1990). Faculty Publications: Department of Entomology. 195.

https://digitalcommons.unl.edu/entomologyfacpub/195

This Article is brought to you for free and open access by the Entomology, Department of at DigitalCommons@University of Nebraska - Lincoln. It has been accepted for inclusion in Faculty Publications: Department of Entomology by an authorized administrator of DigitalCommons@University of Nebraska - Lincoln. 


\title{
Environmental Influences on Soil Macroarthropod Behavior in Agricultural Systems
}

\author{
Michael G. Villani \\ Department of Entomology, \\ NYSAES/Cornell University, Geneva, New York 14456 \\ Robert J. Wright \\ Department of Entomology, \\ University of Nebraska-Lincoln, Lincoln, Nebraska 68583
}

\section{Introduction}

Many basic and applied studies in insect ecology have focused on the proximate and ultimate responses of insect populations to their physical and chemical environment $(2,15,21,27,32,74,82,111,112)$. From an economic perspective, macro- and microclimatic factors can influence the stress that insect populations inflict on plants and the efficacy of management tactics. For above-ground insects, the mechanisms of behavioral response to environmental factors are often observable, if not always apparent to the researcher. However, this is not typically the situation with soil insects. As a result, field studies of soil insects often quantify only the consequences of behavior while the behaviors themselves remain hidden within the soil matrix $(14,103,105)$.

Soil ecology research has been productive at the ecosystem level on such topics as nutrient cycling (18), arthropod regulation of micro- and meso-fauna in below-ground detrital food webs (75), impact of microfauna on soil genesis and structure (87), rhizosphere dynamics (17), and energy dynamics of soil systems (79). These examples highlight the importance of multidisciplinary approaches to research programs that unite expertise in insect ecology, soil 
physics, chemistry, and microbiology as well as systems analysis and modeling (87). Considerable interest also exists in the relationships within soil communities, but these studies have focused primarily upon nonagricultural systems $(71,108)$ and on the more abundant microarthropod members of the soil fauna (106-109).

Ecological, morphological, and physiological adaptations of nonagricultural soil arthropods have been discussed in the literature $(8,10,26,59)$; however, insects that are agricultural pests primarily in their immature soil-inhabiting stages have often been studied in detail only in their more accessible adult stage. Although the mobile adult stages of soil pests often determine initial habitat and host selection, a considerable proportion of subsequent host and habitat selection is performed by immatures in the soil, if host or habitat quality deteriorates over time.

A major obstacle to the study of soil insect ecology has been the inability to follow soil insect movement and feeding behavior in situ $(3,14,33,34,103$, 105). It is critically important in these studies to minimize the disturbance of the soil system through experimental manipulations. R. L. Rabb (cited in 103) notes that the greatest problem with studies of soil insects is that the system is altered through its study. Also, research workers often fail to consider dominant mass and energy transport mechanisms in soil ecosystems. Differences in above- and below-ground environments may alter soil insect sensitivity (over ecological and evolutionary time) to shifting environmental conditions, the movement of chemical cues from potential food sources to soil herbivores, and the mechanisms for soil insect host-finding behavior when compared to terrestrial organisms.

In this review we briefly outline several basic principles of soil physics as they relate to soil insect movement and host-finding behavior, to provide a general understanding of the environment in which soil macroarthropods exist. We then selectively review the entomological literature in light of these principles to stress the need to evaluate soil insect behavior within the soil matrix when trying to understand the underlying mechanisms that produce observable behavior. Finally we briefly discuss the importance of behavior in the management of soil insects.

\section{The Soil Environment}

\section{Physical Components of the Soil}

Hillel (46) states that the three phases of nature are represented in soil: the solid phase constitutes the soil matrix; the liquid phase consists of soil water which always contains dissolved substances so that it should properly be called the soil solution; the gaseous phase is the soil atmosphere. The solid matrix of the soil includes particles that vary in chemical and mineralogical composition as well as in size, shape, and orientation. It 
also contains amorphous substances, particularly organic matter that is at-
tached to the mineral grains and often binds them together to form ag-
gregates. The organization of the solid components of the soil determines
the geometric characteristics of the pore spaces in which water and air are
transmitted and retained. Soil water and air vary in composition, both in
time and space. The relative proportions of the three phases in the soil
vary continuously and depend upon such variables as weather, vegeta-
tion, and management.

Water in the soil environment can be found in the solid, liquid, and gaseous phases. The amount of liquid water found in soil may be described in terms of soil wetness per unit weight (or volume), or alternately as soil moisture tension, which can be defined as those forces "responsible for the soil's ability to attract and hold pure water" (4). Increased tension is correlated with decreasing soil wetness, but no theory for the prediction of the tension-versus-wetness relationship has been devised from basic physical principles (46).

The relative concentration of oxygen, $\mathrm{CO}_{2}$, and water vapor in the soil atmosphere is often considerably different than in open air. Reduced oxygen concentrations and heightened $\mathrm{CO}_{2}$ concentrations in soil air are the consequences of biotic respiration and biochemical soil processes. The relative humidity in an unsaturated soil will be under $100 \%$, but generally within $2 \%$ of saturation. The deficit to saturation will depend in part upon the soil temperature and moisture content and will be influenced by the soil's osmotic and matric potential $(4,46)$.

Soil temperature influences the rates and directions of soil physical processes, energy, and mass exchange with the atmosphere, the types and rates of chemical reactions, and the biological processes that take place in the soil (46). Soil color, height of the sun, slope of the land (degree and direction), soil moisture content, porosity of the soil, mineral composition, percent organic matter, and vegetation will all influence the heating of the soil surface and the movement of heat through the soil profile (22).

\section{Soil Temperature Flux}

On a daily basis the difference between the maximum and minimum temperature decreases with depth in the soil. There is also a delay of maximum and minimum soil temperatures compared with surface temperatures; the size of the delay increases with the depth of the soil. On an annual basis, in temperate regions, the soil profile undergoes a cycle similar to the diurnal cycle. As would be expected, in the upper soil layers the maximum and minimum temperatures are found in the warmest and coolest season, respectively; however, deeper in the soil, temperature oscillations are dampened and upper layer values and temperature maximums and minimums are delayed. For example, at the 7 meter depth the highest temperatures are found in the first part of winter while the lowest occur in mid summer (58). The amplitude of the annual and diurnal temperature waves through the soil becomes smaller 
with the distance from the surface. This is because heat is stored in each succeeding layer so that less heat is passed on to the next layer (12). In the spring and fall a transition period occurs when the soil temperatures are more or less uniform throughout the upper soil layer. This process is similar to the spring and fall overturns of aquatic systems (113).

\section{Soil Moisture Flux}

Soil moisture tension determines the amount of water remaining in the soil at equilibrium and is a function of the sizes and volumes of the water-filled pores (matric potential), and the presence of solutes in the soil (osmotic potential) and gravity. It is the primary factor in determining liquid water movement in the soil profile and the availability of soil water to plants and animals.

Soil moisture can alter the movement of heat through the soil profile. The movement of water (rain, snow melt) through the soil can appreciably alter the soil thermal environment. Differences in subsoil texture can vary considerably within and among fields that appear, superficially, to be very similar. These factors can influence moisture movement and retention, and thereby influence heat transfer. In moist unsaturated soils, temperature gradients cause moisture movement, so that moisture will tend to redistribute itself when the temperature gradient changes. This moisture movement, in both the liquid and vapor phases, gives rise to a transport of both sensible and latent heat, which again influences temperature distribution (22). Separating liquid water movement from vapor movement is difficult because overall soil water movement involves a complex sequence of short-range liquid flow, vaporization, vapor flow, condensation, liquid flow, and revaporization (80).

\section{Gas Exchange in the Soil}

The exchange of gases within the soil, and between the soil and the atmosphere above is facilitated by convection and diffusion. Convection contributes to significant aeration at the surface in soil, where there are large and continuous pore networks. Rates of aeration may be influenced by changes in barometric pressure, temperature gradients, and wind gusts (46). Soil factors such as temperature, relative humidity, surface texture, and the tortuousity and continuity of soil pores (4) affect the diffusion of gases in the soil. Independent of soil condition, diffusion of volatiles depends primarily upon concentration gradients, their molecular weight (44) and solubility.

\section{Insects in the Soil Environment}

\section{Response to Temperature}

A seasonal pattern of vertical movement apparently associated with soil temperature has been documented in several species of scarab grubs (19, 
$31,73,98)$, wireworms $(9,38,51,68)$, and litter-inhabiting microarthropods $(20,106)$. Movement down into the soil in the winter protects the inactive insect from short, unseasonably cold spells, which do not reduce temperatures in lower soil layers. Dowdy (25) correlated the effects of soil temperature with movement patterns of an entire complex of soil macroarthropods. He noted a spring and fall overturn of temperatures in the soil profile and macroarthropod movement patterns that appeared to be associated with the timing of the overturn. Many species initiated movement upward or downward when exposed to soil temperatures of approximately $4-7^{\circ} \mathrm{C}$. The vertical movement of Japanese beetle (Popillia japonica) grubs paralleled changes in air temperature but lagged 4-6 days behind fluctuations in air temperature (43), which was apparently the length of time it took for temperatures to change at the depth of the grubs.

In many field studies only one environmental factor was considered. Movement away from the soil surface in the middle of the summer was often associated with high soil temperatures, although it may have been caused by a decrease in soil moisture (which was not measured). Additionally, many studies did not identify soil insects beyond family or genus, thus obscuring any species-specific behavior patterns that may have existed. Although ignored in some past research, species-specific responses to the soil physical environment may be important, even in insect groups which otherwise have similar biological characteristics (e.g. voltinism, seasonal phenology, host range). Finally, different stimuli may vary in importance at different times during the year. The physiological state of the organism influenced by past feeding and environment (temperature, moisture, etc) may alter insect behavior (2).

Species-specific responses to temperature may influence periods of feeding activity of different species. Ctenicera destructor and Hypolithus bicolor, two commonly co-occurring wireworms in Canada, have significantly different ranges of optimal temperatures for activity that are based on laboratory studies (115). These findings have been corroborated in field studies with numerous wireworm species $(11,30,54,61,116)$. Species-specific preferred temperature ranges have also been reported for scarab grubs, from both correlative field (98) and laboratory studies (105).

Other studies focused on identifying preferred temperatures and understanding behavior patterns responsible for soil insect movement correlated with temperature. In the laboratory, Melanotus communis larvae placed in a tube-shaped chamber filled with moist sand were exposed to a temperature gradient over the length of the tube (35). Wireworms tended to remain in portions of the tube held at 17-29 C, avoiding temperature extremes above or below this range, but they showed no particular preference within this temperature range. Temperature preferences of wireworms (Agriotes spp. and Limonius califomicus) are influenced by the previous temperature experience of individuals $(13,29)$. Speed of movement in Agriotes spp. was directly related 
to temperature within a range of $8-25^{\circ} \mathrm{C}$. However, if temperatures dropped suddenly from 16 to $6^{\circ} \mathrm{C}$, wireworms were significantly more active (for $2 \mathrm{hr}$ ) compared to wireworms held at a constant $6^{\circ} \mathrm{C}$ prior to the experiment. Falconer concluded this response was in anticipation of further temperature declines to lethal limits (29).

Villani \& Wright (105) radiographed soil blocks in the laboratory to study the response of three scarab grub species, Japanese beetle, European chafer (Rhizotrugus majalis), and Oriental beetle (Anomala orientalis), to temperature flux. Temperature fluctuations had very little impact on the position of European chafer grubs. Population distributions of European chafer grubs within the soil profile were nearly identical in temperature regimes that were both stable $\left(20^{\circ} \mathrm{C}\right.$ throughout profile over duration of experiment) and fluctuating (reduction of temperature from 20 to $2^{\circ} \mathrm{C}$ in $6^{\circ}$ weekly increments, then returned to $20^{\circ} \mathrm{C}$ ). This unresponsiveness to temperature conforms with field observations (98) that indicate that European chafer grubs are often found in the upper turf root zone well into early winter and early spring; at times they feed in the upper root zone under snow if this zone is not frozen. In contrast, the other two scarab species responded rapidly to shifting temperatures. Japanese beetle grubs fed in the upper root zone in the stable temperature regime, whereas in the shifting temperature regime grubs moved from the upper root zone downward with the onset of cooling soil $\left(14^{\circ} \mathrm{C}\right)$ and returned to the surface as temperatures increased. Oriental beetle movement appeared more variable, but again grubs tended to remain in the upper root zone in the stable treatment and to respond to lower soil temperatures $\left(8^{\circ} \mathrm{C}\right)$ by moving down in the soil profile. An increase in soil temperatures moved a portion of the Oriental beetle population back to the upper root zone while not affecting the median population value. Similar movement behavior of Oriental beetle populations in response to warming has been observed in the field (105).

Although not considered in many studies, gradients of temperature may have modified the soil moisture conditions, which usually were assumed to be uniform within the chamber. Unless the ambient air was saturated at all temperatures, differences in vapor pressure deficits in the air may have confounded the presumed response to temperature (72). Few studies have separated the interactive effects of soil moisture and temperature.

\section{Response to Moisture}

In addition to a response to seasonal changes in soil temperature, soil insects show shorter term patterns of movement to and from the soil surface in response to rainfall and irrigation, and to soil drying, respectively. Early workers correlated changes in moisture conditions with the occurrence, persistence, and damage potential of soil insects in the field $(51,61,98,115)$. 
Limonius californicus avoided dry soil and died of desiccation if placed in air-dry soil for several hours; saturated soil caused almost complete discontinuance of activity and sometimes death (13). For Agriotes spp. wireworms, high moisture soil may have trapped rather than attracted wireworms by lessening their burrowing ability $(64,65)$. Feeding on potato baits was greater in drier soil than very wet soil, but this was due to an inability to reach the bait rather than being an effect on feeding activity.

Radiographs of soil blocks containing third instar Japanese beetle, Oriental beetle, European chafer, and Northern masked chafer (Cyclocephala borealis) grubs indicated that these species respond to simulated irrigation and drought (105). Individual grubs of all species studied moved upward after the addition of moisture in dry soils. However, median population response and variation around the median varied among species. European chafers showed the least sensitivity to decreased soil moisture; this last fact may be related to their ability to escape rapidly from extreme conditions.

An alternative to escaping stressful physical environments by movement is the alteration of the soil environment by insect behavior. Wireworms and earthworms will construct semipermanent earthen cells under dry soil conditions (103; M. G. Villani, unpublished data). Scarab grubs also create semipermanent chambers in soil if they are not actively moving through the soil profile (105; Figure 1). By forming a temporary cavity with their body and disengaging themselves from the soil, these soil insects may be altering their microenvironment, creating a nearly saturated chamber. Coupled with a curling of the insect within the cell, this chamber reduces moisture loss from evaporation.

Different life stages or morphological characteristics may result in variations in their resistance to moisture loss, in an apparently adaptive pattern. Of all the immature stages of the wireworm L. californicus, those most resistant to moisture loss were eggs and pupae (50), the stages least able to escape unfavorable conditions through movement, or to modify their environment through their behavior. Evans (28) indicates that the wireworm cuticle acts as a semipermeable membrane. Loss of moisture from a soil insect will partially depend upon the degree of sclerotization of the cuticle: heavily sclerotized soil insects such as wireworms should be less vulnerable to cuticular moisture loss than are less sclerotized forms, such as grubs, maggots, and rootworms.

Although soil moisture was often the variable measured, insects are responding to the evaporative capacity of the soil $(1,2,16)$. In a series of experiments comparing uniform relative humidity gradients of three different temperatures, Lees $(64,65)$ found wireworm behavior correlated better with differences in saturation pressure deficit than with relative humidity. He concluded that the humidity receptors of a wireworm acted more like an evaporimeter than a hydrometer. The intensity of the humidity reaction in Agriotes 


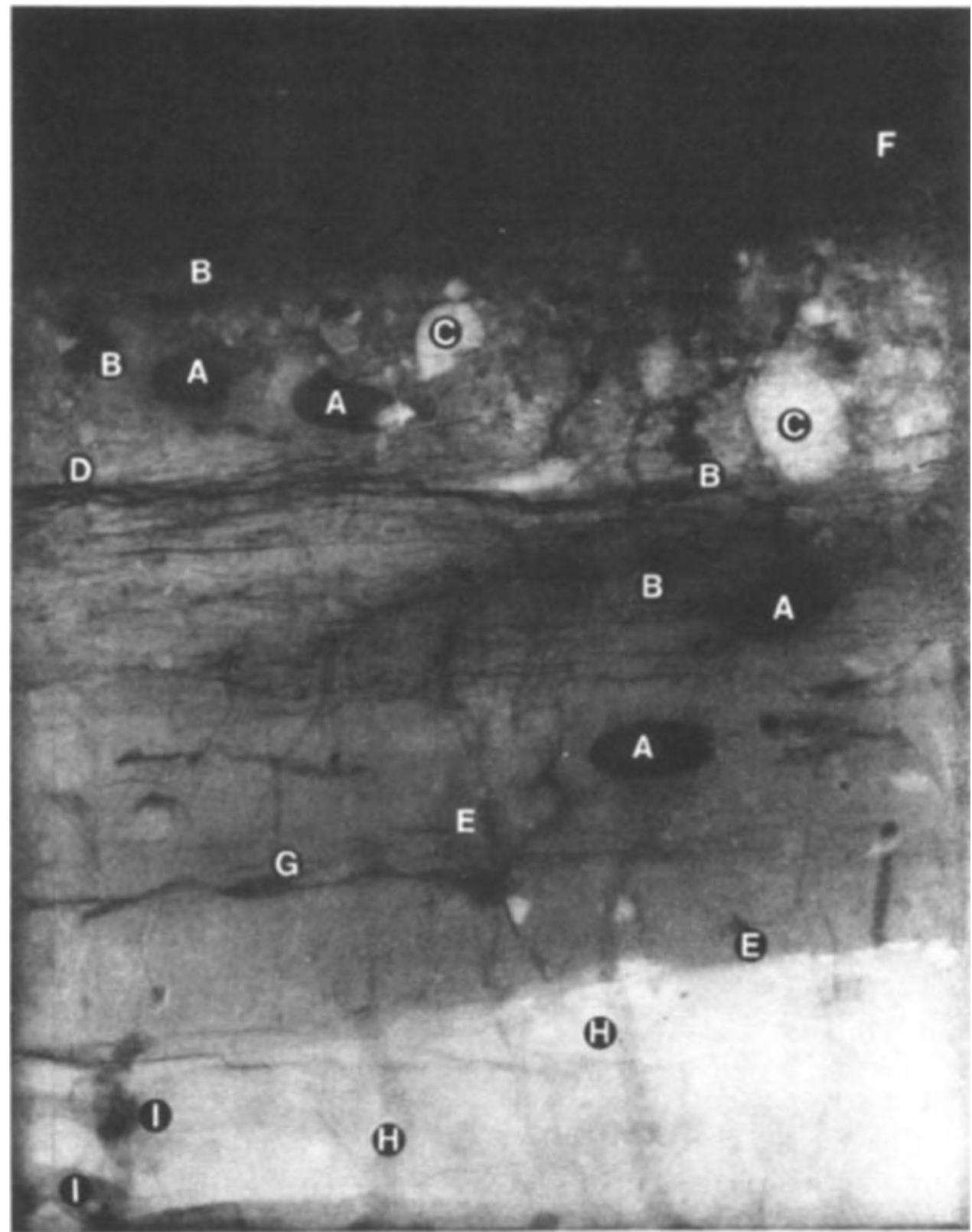

Figure 1. Radiograph of field collected soil block taken from moist, stratified soil of a weedy orchard. Two grub species (A: Phyllophaga sp.; B: European chafer) were introduced to the top of the soil, and soil was allowed to dry for 2 weeks before this radiograph was made. (A) Third instar Phyllophaga grub in earthen chamber; (B) third instar European chafer grub in earthen chamber; (e) rock; (D) interface of topsoil and sandy horizon; (E) interface of sandy and clay horizon; (F) soil surface; $(\mathrm{G})$ burrowing of endemic soil organism; (H) burrows of tunneling Phyllophaga grub (105, reproduced with permission from Entomological Society of America). 
spp. is dependent on the evaporation of water from some site on the body (probably the head). Wireworms preferred relative humidities of $100 \%$ and were increasingly sensitive to humidity gradients as relative humidities approached $100 \%$.

The drying power of the soil atmosphere can vary with temperature even though relative humidity remains the same $(2,16)$. In a soil with an atmospheric moisture less than saturated, soil tension levels govern the rate of water loss rather than the absolute amount of moisture in the soil. Although it is common for entomologists to measure and report soil moisture in terms of percent moisture, the use of soil tension concepts (such as percentage of field capacity) may have more ecological significance.

\section{Insect Perception of the Soil Matrix}

In reviewing the interactions among roots, soil, microbes, and other fauna, Coleman (17) states "organisms within the [soil] community play markedly different roles as a function of size. Thus, organisms (microbes, protozoa, small nematodes, rotifers) that exist in water films, in various micropores within the soil, are probably operating in quite a different world from organisms that move into and out of pores independently of water films. A third, and perhaps more distinctive category are those members of the macrofauna that move soil around by external means...."

Extending this concept, a soil macroarthropod's perception of the soil matrix is likely to change as it grows. Neonates exist effectively as microarthropods, with their mobility restricted to existing pores in the soil. Consequently, the gross structure (soil fabric) of the soil is not a major obstacle to movement by early instars. The soil fabric does add, however, to the total pore composition and organization of soil, making insect movement dependent upon the number and continuity of the pores. Increased tortuosity of the pore space impedes movement and increases the actual distance that must be traveled from point $A$ to point $B$ in the soil (it also affects movement of chemical and physical stimuli from the environment to the insect). Water-filled soil pores will inhibit movement and functionally increase tortuosity. As the soil insect grows, an increasing proportion of the soil pore space becomes unavailable to the insect for free movement. As this occurs, pore space per se may become less important in impeding soil insect movement than gross soil structure (insect movement among soil aggregates) and aggregate density (insect movement through the aggregates). The presence of preexisting semipermanent soil channels created by soil macrofauna (arthropods, earthworms, and small vertebrates) and roots may also affect the free movement of larger soil fauna $(17,41 a)$. Depending upon the ultimate size of the soil insect species in question and their rate of growth, a greater or lesser proportion of the soil matrix may be unavailable for rapid and free movement (Figure 2). Factors govern- 
ing aggregate formation include root activity, surface cover, traffic, moisture and micro- and macro-organisms. The realization that primary soil textural units may not completely explain the activities of macroscopic soil organisms has stimulated an interest in the higher organizational units of soil (17).

Movement of neonate western corn rootworm (Diabrotica virgifera virgifera) larvae is affected by soil texture and bulk density $(41 a, 95)$. Since corn rootworm eggs commonly occur $10-20 \mathrm{~cm}$ below the soil surface, in some soils the ability of rootworm larvae to find hosts may be greatly influenced by the growth of corn roots, or other naturally occurring burrows or fractures in the soil.

\section{Host Finding}

Studies of above-ground insects have dominated much of the behavioral research related to insect host-finding (27). Host-finding is often described as one step in a continuum of behaviors ranging from host-habitat location to
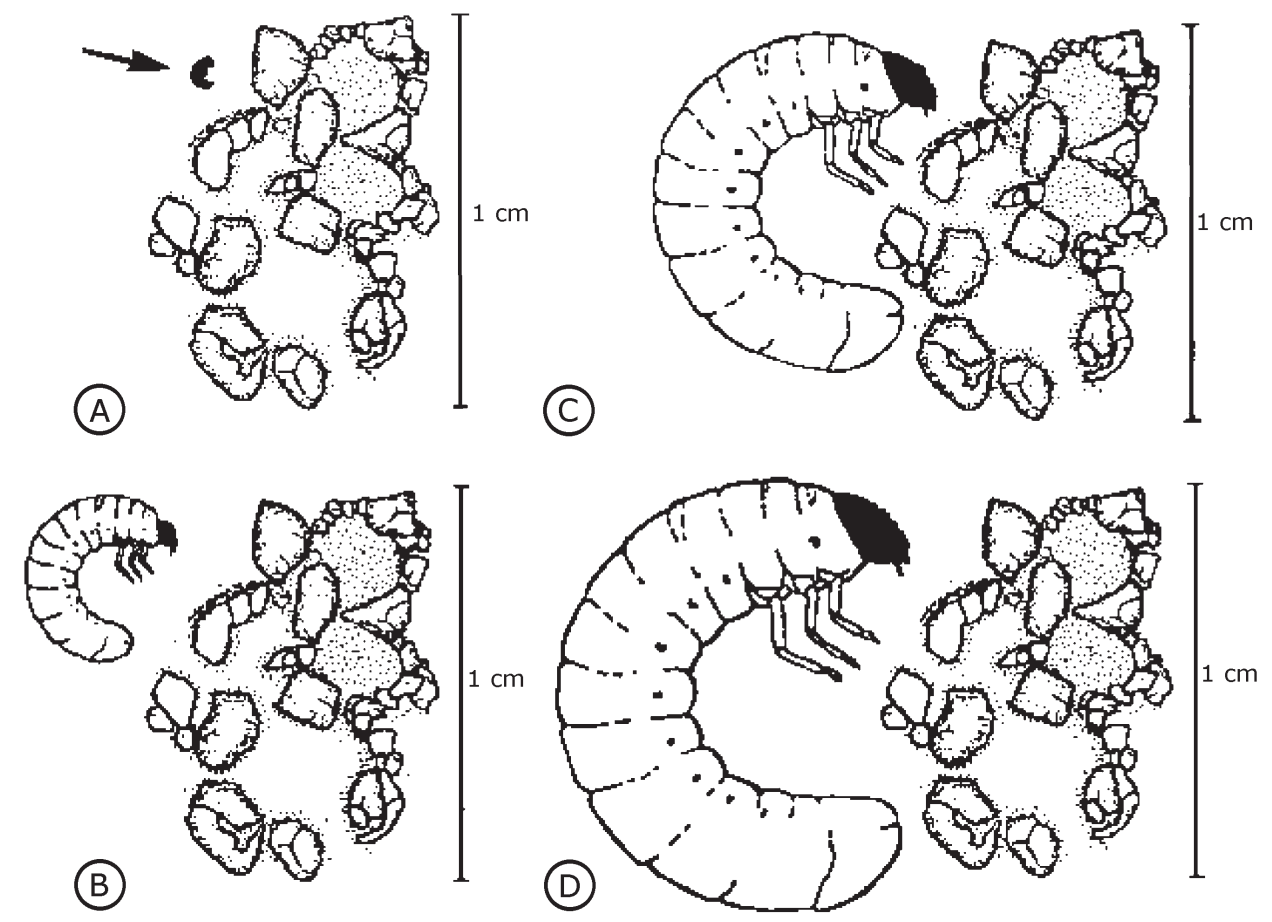

Figure 2. Japanese beetle grub at egg hatch (A), late-first (B), mid-second (C), mid-third instar (D). Relative grub sizes are based on Tashiro (98). Grubs are compared with a representation of a square $\mathrm{cm}$ of typical loamy sand soil. The soil is at ca. field capacity with many larger pores free of available liquid water (dotted areas). (Soil block adapted from Coleman 1985; courtesy of Blackwell Scientific Publ. Inc.) 
host-finding, leading to host-acceptance and feeding (47). This discussion focuses on host-finding behavior and does not include host-acceptance or feeding behavior of soil insects once they reach a host plant.

Although host-habitat location and host-finding may begin with choices made by mobile females in oviposition behavior, host-finding is often still important to the soil-inhabiting immature stages. The distance traveled to find a host may vary depending on both adult behavior and the life stage of the specific insect. For example, although the female onion maggot fly (Delia antiqua) lays eggs near the appropriate host plant, neonate onion maggots must move some distance to an appropriate host immediately after egg hatch in order to survive. Additionally, when feeding on onion seedlings, onion maggots must consume more than one plant to complete their development, so the ability to locate new hosts is important for later instars as well. In other insects such as corn rootworms, the adult female lays eggs in an appropriate habitat (a corn field), but the eggs do not hatch until the next year, at which time corn seeds may be sown offset from the previous year. In this case, neonate larvae may have to move relatively great distances to find hosts. Other insects such as wireworms and scarab grubs often overwinter as larvae and must locate hosts first as neonates, and again in spring when they return to the soil surface in search of food.

Plant-derived chemicals influence host-finding by soil-inhibiting phytophagous insects. Thorpe et al. (100) demonstrated that when given a choice wireworms concentrated in sand moistened with host plant extracts rather than with water. Wireworms also responded to single chemical compounds such as aspartic acid and asparagine and to a lesser extent, sucrose. Wireworms released in soil that is sandwiched between plates of glass moved less rapidly in the presence of active compounds. They concluded that wireworms use orthokinesis in host-finding and compared this with work by Lees (64) and Falconer (29) who concluded that similar mechanisms were used by wireworms to remain in preferred conditions of humidity and temperature, respectively.

Soil insects with more restricted host ranges respond to secondary plant chemicals specific to their appropriate host range. Onion maggot larvae respond to many of the same organic sulfides and mercaptans responsible for adult oviposition behavior $(69,70)$. Twenty-seven such compounds were attractive to neonate onion maggots from a distance of $1 \mathrm{~cm}$ in petri dish bioassays. Soni \& Finch (89) characterized the dosage-response relationship of these chemicals at ranges from 10,000 to $0.1 \mathrm{~nL}$. Onion maggots showed the greatest attraction to intermediate concentrations whereas the lowest and highest concentrations prompted no activity and repellancy, respectively. When rotting onions were inoculated with Klebsiella spp. bacteria, several non sulphur compounds (ethyl acetate, tetramethyl pyrazine, and n-heptanal) increased the activity of dipropyl disulfide, a major attractant found in damaged onions (49). 
Carrot fly (Psila rosae) larvae respond to volatile chemicals released from carrot roots $(52,83)$. Carrot cultivars exhibiting resistance to carrot fly attack in the field were found to release almost five times fewer active volatiles than did susceptible carrot cultivars (41). Five major compounds were attractants of carrot fly larvae, and one compound had repellent qualities (84).

Wheat bulb fly (Leptohylemyia coarctata) larvae feed only on a few grain crops, such as wheat, rye, and barley, whereas oats are a nonhost. Larvae responded positively to wheat plant constituents over short distances $(\mathrm{ca} .1 \mathrm{~cm})$ in a petri dish bioassay that used either cubes of gel in which wheat seedlings had been grown or gels made with wheat seedling extracts (91). Based on petri dish bioassays and studies of larval host-finding in the soil, the active compounds are most concentrated in the stem region, with some activity present in the root as well. Neonate larvae moved upwards in the soil at a fairly steep angle and then moved laterally near the surface until they contacted a plant (67). In contrast to previous work, which assumed that the host compounds functioned as attractants, Scott (86) described the active compounds as arrestants, a conclusion based on study of larval movement. Sugars, casein, potato extract, and various fatty acids were inactive when tested in gels in petri dish bioassays. More recent work summarized by Greenway et al. (40) has characterized an arrestant from wheat as a polyphenolic compound, possibly a glycoside. Laboratory and greenhouse studies indicate that oats contain a polyhydroxylated aliphatic compound that interferes with the arrestant properties of the wheat extract.

In contrast to work aimed at identifying specific plant chemicals responsible for host location, Klinger $(56,57)$, identified carbon dioxide as an important nonspecific chemical influencing soil insect host-finding in several cases. Many soil insects $(24,36,44,52,56,57,76,90,96)$ are attracted to carbon dioxide. Carbon dioxide is released by decaying organic matter in the soil as well as by living plant roots. Both phytophagous and saprophagous insects may use $\mathrm{CO}_{2}$ to locate food sources.

Carbon dioxide diffuses over longer distances in the soil air than do many plant volatiles with higher molecular weights $(39,52)$. However, because carbon dioxide is highly soluble in water, insects may find it hard to orient to carbon dioxide in wet soils (46). Insects with both broad and narrow host ranges respond positively to gradients of carbon dioxide. For insects with a broad host range, such as scarab grubs and wireworms, carbon dioxide, perhaps in combination with nonspecific plant root exudates, would be adequate for host-finding (53). Because carbon dioxide is not specific to particular food sources, insects with more restrictive host ranges must depend upon additional plant-specific chemicals, chemical blends, or nonchemical cues that are encountered once the insect attempts to feed on the plants to determine the suitability of a potential host. 
Assays conducted where chemicals diffuse through open air may poorly model intact soil systems. Generally, movement of chemicals in the soil is more predictable than that in the air because no disruptive forces such as winds alter chemical gradients. However, soil factors such as moisture, texture, and compaction modify the speed and distance with which chemicals can diffuse through the soil atmosphere. Soils saturated with moisture have relatively little soil atmosphere and predictably slow the diffusion of chemicals from plants to soil insects searching for hosts.

Jones \& Coaker (53) hypothesized a correlation between the types of chemicals associated with host orientation and the degree of host specialization of both above- and below-ground insects. They suggested that attraction to carbon dioxide and other primary metabolites was a primitive characteristic common to many below-ground saprophagous insects. The evolution of specialist phytophagy was associated with the ability to orient to secondary plant chemicals while retaining the primitive response to primary chemicals. Oligophagous and monophagous soil insects are known to respond to both carbon dioxide and secondary plant chemicals. Branson (5) interpreted his research on the response of western corn rootworm larvae (WCR) to plant roots in light of the hypothesis of Jones \& Coaker. Branson suggested that although polyphagous WCR larvae responded to nonspecific primary metabolites such as carbon dioxide, the recent adaptation of WCR to corn might explain its lack of response to plant compounds specific to corn, responses otherwise predicted for an oligophagous insect. The recent evolutionary history of WCR on crop species is also suggested by the fact that WCR are attracted to and feed on the toxic roots of sorghum (6). Hibbard \& Bjostad (44) have demonstrated that volatiles from corn seedlings as well as carbon dioxide are attractive to western corn rootworm larvae. Whether the volatiles are specific to corn or grasses is not known. Jones \& Coaker's hypothesis is difficult to evaluate, because few studies have examined the response of soil insects to both primary (including carbon dioxide) and secondary chemicals, and fewer still have evaluated the relative importance of various potential mechanisms to host-finding in the field.

Past research has often neglected to investigate how suspected active compounds function in the soil environment and how such compounds are perceived by soil insects. Villani \& Gould (103) demonstrated that wireworms located plants in the soil, often rapidly and in an apparently directed manner, whereas in the absence of food, wireworms moved randomly (Figure 3). Similarly, both carbon dioxide and plant exudates are known to be involved in the host-finding behavior of at least one scarab grub species, Costelytra zealandica $(36,97)$. The process used by scarab grubs to find host plants in the soil has not been identified. Recent studies of scarab grub behavior (M. G. Villani, unpublished data) in simple soil systems examine the importance of gravity, environmental conditions, and host plants in host-finding by scarab grubs. 
Grub behavior was examined by alternately positioning a layer of irrigated growing sod and moist sponge at the top, bottom, or sides of soil arenas. This arrangement results in nearly symmetrical gradients of increasing soil moisture away from the center of the arena.

When grubs were allowed to choose between sod and sponges positioned on the arena sides, both species were most often found feeding in the sod. In contrast, in arenas where sod and sponges were positioned alternately on the top and bottom, Japanese beetle grubs moved upwards to the soil surface and European chafers moved downward into the soil profile regardless of the relative position of sod or sponge. This initial movement was mitigated some-

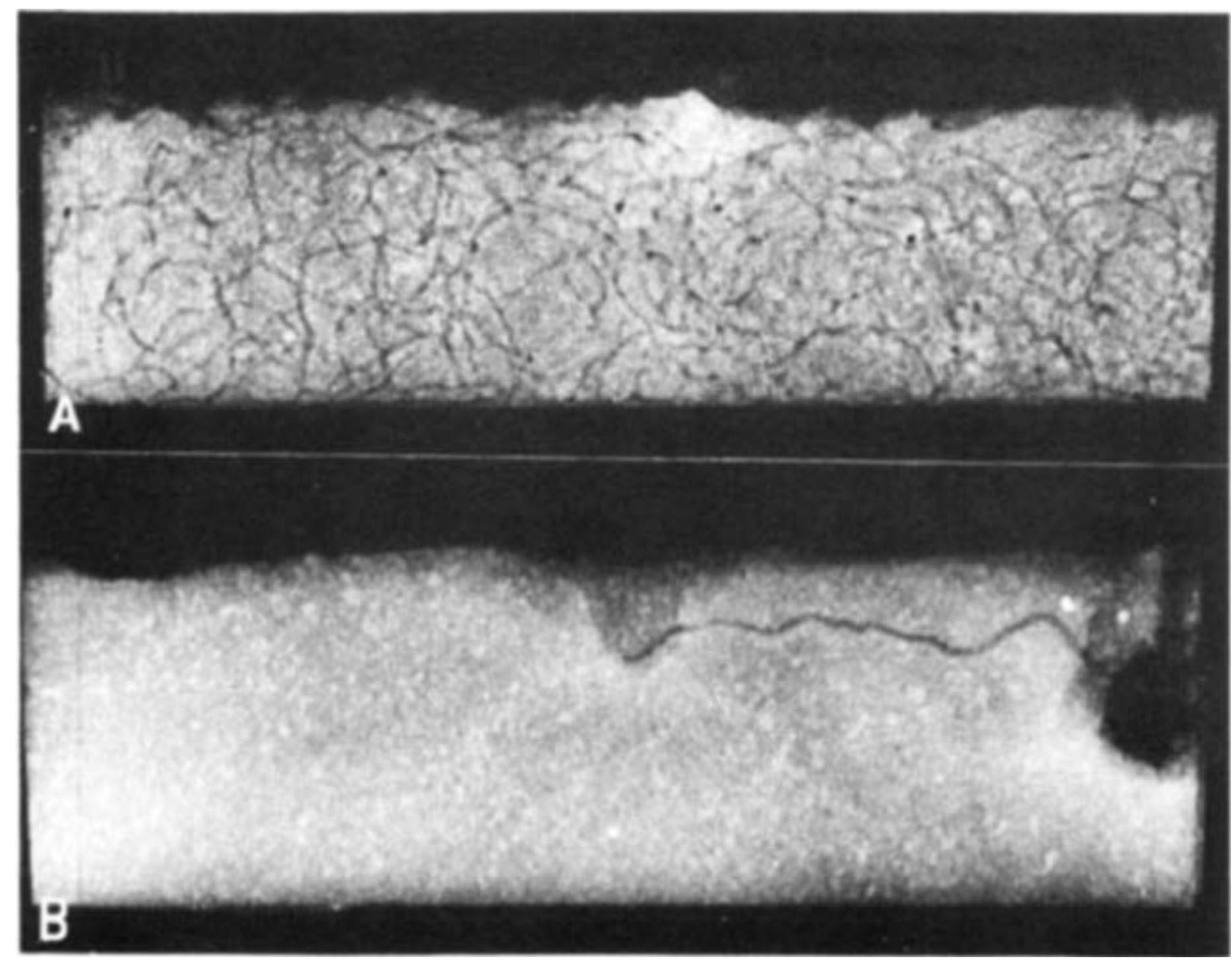

Figure 3. (A) Radiograph of soil arena without host plant with one corn wireworm (Melanotus communis) placed in the center of arena, head downward, ca. $1 \mathrm{~cm}$ from soil surface. Radiograph was exposed ca. $12 \mathrm{hr}$ after introduction of insect. Note complex matrix of tunnels that were made apparently in search of host. (B) Radiograph taken $2 \mathrm{hr}$ after corn wireworm was placed as in (A). Tobacco plant (dark image on right of radiograph) had been placed in arena four days previously. The apparent directed movement of wireworm tunnel to host is typical of active wireworms (103, reproduced with permission from Entomological Society of America). 
what over time as grubs of both species moved away from areas without food and contacted turfgrass roots. These results suggest that the impact of both intrinsic and extrinsic factors must all be considered when analyzing soil insect host-finding behavior.

\section{Interactions among Soil Insects, Control Agents, and the Environment}

Studies of agriculturally important soil insects have often attempted a better understanding of pest behavior, ultimately to develop improved management strategies. Despite our relative lack of understanding of mechanisms directing soil insect behavior, applied researchers have used available information to manage soil insects (105a). Methods for soil insect control that depend upon a knowledge of insect behavior include: cultural measures $(63,78$, $88)$, baits $(23,45,49,66,110)$, antifeedants $(62,101,102,104)$, host plant resistance (7), and biological and chemical control agents $(37,55,84,114)$.

To illustrate the importance of improved understanding of interactions among soil insect behavior, various control tactics, and the environment, we have found it useful to group control agents of soil insects in categories based on their ability to move and reproduce within the soil profile.

The first group of control agents are the synthetic (e.g. carbamates, organophosphates, pyrethroids, etc) soil insecticides. These agents are passively mobile and nonreplicating (potentially, microbial toxins such as Bacillus thuringiensis or avermectins could be included in this group). Physical factors that result in the movement of target insects as little as $1 \mathrm{~cm}$ into the soil profile may put soil insects out of the effective active zone of some chemical control agents. Conversely, highly mobile soil insecticides will move beyond the root zone and will also be ineffective in controlling soil insects. Contact between the toxic agent and target soil insect is determined primarily through soil factors influencing its passive percolation through the profile (texture, compaction, and organic matter), movement with growing roots, mechanical incorporation into the soil profile through cultivation, and the activity and location of the target insect in relation to the distribution of insecticide residue in the soil profile $(14,42,60,99,105)$.

A second grouping of control agents includes the biological insecticides. This group is generally considered to be passively mobile but capable of replication (e.g. B. popilliae, Beauveria bassiana, Metarrhizium anisopiiae, and various viral agents) $(48,55,92-94)$. As with nonreplicating control agents, the location of the soil insect in the profile determines the degree of overlap of control agent and target. Unlike nonreplicating agents, the behavior of the target insect is important to the spread of the pathogen. Normal or pathogen-induced behaviors may cause infected individuals to move outside of the normal range of the target or the optimal range of pathogen replication. 
Finally, insect predators and parasitoids (including entomogenous nematodes such as Steinernema feltiae, Heterorhabditis heliothidis) are both mobile and replicating are interesting because their effectiveness depends on the interaction of the soil environment with both the agent and target. Initial attack and subsequent spread through the target population depends upon the overlap of agent and target in both space and time within the soil environment $(37,77,81,85,114)$. Differences in predator, parasitoid, and parasite behavior in the soil environment (e.g. response to soil texture, moisture, temperature, root volatiles, and root exudates) should be taken into account when evaluating these agents. Studies attempting to evaluate the host-finding behavior of these agents should be designed in light of the confounding nature of the soil environment outlined above.

\section{Conclusions}

In this review we have suggested that a more systematic and experimental approach to the study of soil insect ecology is required to better understand and manage agriculturally important soil insects. Such factors as species, size, and previous experience must be taken into account when soil insect behavior is studied, as it is in research involving above-ground insect species. We also believe that a more thorough appreciation of the physical attributes of soil systems will improve our ability to design appropriate experiments to study soil insect movement and host-finding behavior. Due to a lack of appropriate techniques, the consequences rather than the processes of soil insect behavior have been measured. Implicit in our discussion is that soil insects must ultimately be studied within the soil environment in model systems and in the field to determine the importance of various behavioral mechanisms that often are first demonstrated in nonsoil studies.

\section{Acknowledgments}

We would like to thank G. Brust, C. Eckenrode, S. Eigenbrode, F. Gould, T. Martinson, L. Meinke, W. Roelofs, P. Schroeder, and A. Shelton for reviewing drafts of this manuscript. We are grateful for the patience and assistance of J. Ogrodnick, R. Sticht, and B. Aldwinkle in developing the figures included in the text. F. Consolie and L. Preston-Wilsey assisted in literature search and technical support. We would also like to acknowledge R. L. Rabb and F. Gould for providing an early forum from which the ideas expressed in this review were developed. Funding to M. G. Villani through a University of Nebraska-Lincoln Research Council Visiting Scholar Grant supported the writing of this manuscript. 


\section{Literature Cited}

1. Altner, H., Loftus, R. 1985. Ultrastructure and function of insect thermo- and hydroreceptors. Annu. Rev. Entomol. 30:273-95

2. Andrewartha, H. G., Birch, L. C. 1954. The Distribution and Abundance of Animals. Chicago: Univ. Chicago Press. 782 pp.

3. Amason, A. P., Fuller, R. A., Spinks, 1. W. 1950. An electronic method of tracing the movement of soil inhabiting insects. Science 3:5-6

4. Brady, N. C. 1974. The Nature and Properties of Soils. New York: Macmillan. 639 pp. 8th ed.

5. Branson, T. F. 1982. Olfactory response of larvae of Diabrotica virgifera virgifera to plant roots. Entomol. Exp. Appl. 31:303-7

6. Branson, T. F., Guss, P. L., Ortman, E. E. 1969. Toxicity of sorghum roots to larvae of the western corn rootworm, J. Econ. Entomol. 62:1375-78

7. Branson, T. F. Welch, V. A., Sutter, G. R., Fisher, J. R. 1983. Resistance to larvae of Diabrotica virgifera virgifera in three experimental maize hybrids. Environ. Entomol. 12:1509-12

8. Brown, A. L. 1978. Ecology of Soil Organisms, London: Heineman. 116 pp.

9. Bryson, H. R. 1935. Observations on the seasonal activities of wireworms (Elateridae). J. Kans. Entomol. Soc. 8:131-40

10. Burges, A., Raw, F. 1967. Soil Biology, London: Academic. 532 pp.

11. Burrage, R. H. 1963. Seasonal feeding of Ctenicera destructor and Hypolithus bicolor (Coleoptera: Elateridae). Annu. Entomol. Soc. Am. 56:306-13

12. Campbell, G. S. 1977. An Introduction to Environmental Biophysics. New York: Springer-Verlag. 159 pp.

13. Campbell, R. E. 1937. Temperature and moisture preferences of wireworms. Ecology 18:479-89

14. Cheshire, J. M., Keaster, A. J., Ward, R. H., Koirtyohann, S. R. 1987. Seed treatment with rubidium for monitoring wireworm (Coleoptera: Elateridae) feeding on corn. Environ. Entomol. 16:475- 80

15. Cloudsley-Thompson, J. L. 1962. Microclimate and the distribution of terrestrial arthropods. Annu. Rev. Entomol. 7:199-222

16. Cloudsley-Thompson, J. L., Chadwick, M. J. 1964. Life in Deserts. Philadelphia: Dufour Editions. $218 \mathrm{pp}$.

17. Coleman, D. C. 1985. Through a ped darkly: An ecological assessment of rootsoil-microbialfaunal interaction. In Ecological Interactions in the Soil, Br. Ecol. Soc. Spec. Publ. 4, ed. A. H. Filter, D. Atkinson, D. 1. Read, M. B. Usher, pp. 1-21. Oxford: Blackwell Scientific. 451 pp.

18. Coleman, D. C., Anderson, R. V., Cole, C. V., McClellan, J. F., Woods, L. E., et al. 1984. Roles of protozoa and nematodes in nutrient cycling. In Microbial-Plant Interactions, ASA Spec. Publ. 47, ed. D. M. Karl, pp. 17-28. Madison, WI: Am. Soc. Agron. 68 pp.

19. Criddle, N. 1918. The habits and control of white grubs in Manitoba. Ag. Gazette Can. 5:449-54

20. Davis, R. C., Hassel, M., Sutton, S. L. 1977. The vertical distribution of isopods and diplopods in a dune grassland. Pedobiologia 17:320-29

21. Denno, R. F., McClure, M. S., eds. 1983. Variable Plants and Herbivores in Natural and Managed Systems. New York: Academic. 717 pp.

22. DeVries, J. 1963. In situ determination of physical properties of the surface layer of field soils. Proc. Soil Sci. Soc. Am. 33:349-53

23. Doane, J. F. 1981. Evaluation of a larval trap and baits for monitoring the seasonal activity of wireworms in Saskatchewan. Environ. Entomol. 10:335-42

24 . Doane, J. F., Lee, Y. W., Klinger, J., Westcott, N. D. 1975. The orientation response of Ctenicera destructor and other wireworms to germinating corn and to carbon dioxide. Can. Entomol. 107:1233-52 
25. Dowdy, W. W. 1944. The influence of temperature on vertical migration of invertebrates inhabiting different soil types. Ecology 25:449-60

26. Eisenbeis, G., Wichard, W. 1987. Atlas on the Biology of Soil Arthropods. Berlin: Springer-Verlag. 437 pp.

27. Elkinton, J. S., Carde, R. T. 1984. Odor dispersion. In Chemical Ecology of Insects, ed. W. J. Bill, R. T. Carde, pp. 73-92. Sunderland, Mass: Sinauer. 524 pp.

28. Evans, A. C. 1943. Value of the $\mathrm{pF}$ scale of soil moisture for expressing the soil moisture relations of wireworms. Nature 152:21-22

29. Falconer, D. S. 1945. On the behavior of wireworms of the genus Agriotes Esch. (Coleoptera: Elateridae) in relation to temperature. J. Exp. Biol. 21:17- 38

30. Fisher, J. R ., Keaster, A. J . , Fairchild, M . L. 1 975. Seasonal vertical movement of wireworm larvae in Missouri: Influence of soil temperature on the genus Melanotus and Conoderus. Annu. Entomol. Soc. Am. 68: 1071-73

31. Forbes, S. A. 1 907. On the life history, habits and economic relations of white grubs and May beetles. Ill. Agric. Exp. Sta. Bull. 116:447-80

32. Fraenkel, G. S ., Gunn, D. L. 1961. The Orientation of Animals. New York: Dover, 376 pp.

33. Frederickson, C. F . , Lilly, J. H. 1 955. Measuring wireworm reactions to soil insecticides by tagging with radioactive cobalt. J. Econ. Entomol. 48 :438- 42

34. Fuller. R. A., Spinks, J. W., Amason, A. P., McDonald, H. 1 950. Use of radioactive tracers in investigations of soil inhabiting insects. 81st Annu. Rept. Entomol. Soc. Ont., pp. 7- 16

35. Fulton, B . B . 1 928. Some temperature relations of Melanotus (Coleoptera: Elteridae). J. Econ. Entomol. 21:889-97

36. Galbreath. R. A. 1988. Orientation of grass grub Costelytra zealandica (Coleoptera: Scarabaeidae) to a carbon dioxide source. N. Z. Entomol. 11:6-7

37. Georgis, R., Puinar, G. O. Jr. 1983. Effect of soil texture on the distribution and infectivity of Neoplectana glaseri (Nematoda: Steinernematidae). J. Nematol. 15:329-32

38. Gibson, E. H. 1916. The corn and cotton wireworms in its relation to cereal and forage crops with control measures. Farmers Bull. 733:1-7. Washington, DC: USDA.

39. Green, C. D. 1971. Mating and host finding behavior of plant nematodes. In Plant Parasitic Nematodes. Vol. 2, ed. B. M. Zuckerman, W. F. Mai, R. A. Rohde, pp. 247-66. New York: Academic. $347 \mathrm{pp}$.

40. Greenway, A. R., Scott, G. C., Calam, D. H., Smith, M. C. 1976. Chemistry of components in wheat and oats that influence behavior of wheat bulb fly larvae. J. Insect Physiol. 22:445-51

41. Guerin, P. M., Ryan, M. F. 1984. Relationship between root volatiles and some carrot cultivars and their resistance to the carrot fly, Psila rosae. Entomol. Exp. Appl. 36:21 7-24

41a. Gustin, R. D., Schumacher, T. E. 1989. Relationship of some soil pore parameters to movement of first-instar western corn rootworm (Coleoptera: Chrysomelidae). Environ. Entomol. 18:343-46

42. Harris, C. R. 1 972. Factors influencing the toxicity of insecticides in soil. Annu. Rev. Entomol. 178:177-198

43. Hartzell, A., McKenna, G. F. 1939 . Vertical migration of Japanese beetle larvae. Contrib. Boyce Thompson Inst. 11:87-91

44. Hibbard, B. E., Bjostad, L. B. 1988. Behavioral responses of western corn rootworm larvae to volatile semiochemicals from corn seedlings. J. Chem. Ecol. 14:1523-39

45. Hibbard, B. E., Bjostad, L. B. 1989. Corn semiochemicals and their effects on insecticide efficacy and insecticide repellency toward western corn rootworm larvae (Coleoptera: Chrysomelidae). J. Econ. Entomol. 82:773-81

46. Hillel, D. 1980. Fundamentals of Soil Physics. New York: Academic. 412 pp.

47. Hsiao, T. H. 1985. Feeding behavior. In Comprehensive Insect Physiology, Biochemistry, and Pharmacology, Vol. 9, ed. G. A. Kerkut, L. I. Gilbert, pp. 471 -512. New York: Pergamon. 735 pp. 
48. Ignoffo, C. M., Garcia, C. Hostetter, D. L., Pinnell, R. E. 1977. Vertical movement of conidia of Nomuraea rileyi through sand and loam soils. J. Econ. Entomol. 70: 1 63-64

49. Ikeshoji, T., Ishikawa, Y., Matsumoto, Y. 1980. Attractants against onion maggots and flies, Hylemya antiqua, in onions inoculated with bacteria. J. Pestic. Sci. 5:343-50

50. Jones, E. W. 1951. Laboratory studies on the moisture relations of Limonius (Coleoptera: Elateridae). Ecology 32: 284-93

51. Jones, E. W., Shirck, F. H. 1942. The seasonal vertical distribution of wireworms in the soil in relation to their control in the Pacific Northwest. J. Agric. Res. 65:125-42

52. Jones, O. T., Coaker, T. H. 1977. Oriented responses of carrot fly larvae Psila rosae to plant odours, carbon dioxide and carrot root volatiles. Physiol. Entomol. 2 : 1 89-97

53. Jones, O. T., Coaker, T. H. 1978. A basis for host plant finding in phytophagous larvae. Entomol. Exp. Appl. 24:272-84

54. Keaster, A. J., Chippendale, G. M., Pill, B. A. 1975. Feeding behavior and growth of the wireworms Melanotus depressus and Limonius dubitans: Effects of host plant, temperature, photoperiod, and artificial diets. Environ. Entomol. 4:59 1-95

55. Klein, M. G. 1988. Pest management of soil-inhabiting insects with microorganisms. Agric. Ecosyst. Environ. 24:337- 49

56. Klinger, J. 1965. On the orientation of plant nematodes and some other soil animals. Nematologica 11:4-18

57. Klinger, J. 1966. Uber den sitz der $\mathrm{CO}_{2}$ rezeptoren bei der larve von Otiorhynchus sulcatus. Entomol. Exp. Appl. 9:27 1-77

58. Kristensen, K. J. 1959. Temperature and heat balance of soil. Oikos 10:103-20

59. Kuhnelt, W. 1961. Soil Biology, London: Faber and Faber. 397 pp.

60. Kuhr, R. J., Tashiro, H. 1978. Distribution and persistence of chlorpyrifos and diazinon when applied to turf. Bull. Environ. Contam. Toxicol. 20: 652-56

61. LaFrance, J. 1960. The seasonal movement of wireworms (Coleoptera: Elateridae) in relation to soil moisture and temperature in the organic soils of southwestern Quebec. Can. Entomol. 100:801-7

62. Landis, D. A., Gould, F. 1988. Screening for phytoprotectants to guard corn seeds/seedlings from southern corn rootworm feeding injury. J. Entomol. Sci. 23:201-211

63. Lane, M. C. 194 1. Wireworms and their control on irrigated lands. Farmers Bull. No. 1866 Washington, DC: USDA. 15 pp.

64. Lees, A. D. 1943. On the behavior of wireworms of the genus Agriotes Esch. (Coleoptera: Elateridae). I. Reactions to humidity. J. Exp. Biol. 20:43-53

65. Lees, A. D. 1943. On the behavior of wireworms of the genus Agriotes Esch. (Coleoptera: Elateridae). II. Reactions to moisture. J. Exp. Biol. 20:54-60

66. Lehman, R. S. 1933. Field experiments with various poison baits against wireworms, Limonius canus. J. Econ. Entomol. 26:243-52

67. Long, D. B. 1958. Host plant location by the larvae of the wheat bulb fly (Leptohylemyia coarctata Fallen). Proc. R. Entomol. Soc. London (A) 33: 1-8

68. Mail, G. A. 1930. Winter soil temperatures and their relationship to subterranean insect survival. J. Agric. Res. $41: 571$-92

69. Matsumoto, Y. 1970. Volatile organic sulfur compounds as insect attractants with special reference to host selection. In Control of Insect Behavior by Natural Products, ed. D. L. Wood, R. M. Silverstein, M. Nakajima, pp. 133-60. New York: Academic. 345 pp.

70. Matsumoto, Y., Thorsteinson, A. J. 1968. Olfactory response of larvae of the onion maggot, Hylemya antiqua Meigen (Diptera: Anthomyiidae) to organic sulfur compounds. Appl. Ent. Zool. 3:107-11

71. Mattson, W. J., ed. 1977. The Role of Arthropods in Forest Ecosystems. New York: Springer-Verlag. 104 pp. 
72. May, M. L. 1979. Insect thermoregulation. Annu. Rev. Entomol. 24:313-49

73. McColloch, J. W., Hayes, W. P. 1923. Soil temperatures and its influence on white grub activity. Ecology 4:29-36

74. Messenger, P. S. 1959. Bioclimactic studies with insects. Annu. Rev. Entomol. 4:183-206

75. Moore, J. C., Walter, D. E., Hunt, H. W. 1988. Arthropod regulation of micro- and mesobiota in below-ground detrital food webs. Annu. Rev. Entomol. 33:419-39

76. Mouris, A. A. 1962. The attractiveness of $\mathrm{CO}_{2}$ and $\mathrm{N}_{2}$ to soil arthropoda. Pedobiologia 1:299-302

77. Moyle, P. J., Kaya, H. K. 1981. Dispersal and infectivity of the entomogenous nematode, Neoaplectana carpocapsae Weiser (Rhabditida: Steinematidae), in sand. J. Nematol. 13:295-300

78. Nash, K. B., Rawlins, W. A. 1941. Wireworm studies in several potato rotations systems. J. Econ. Entomol. 34:287-90

79. Peterson, H., Luxton, M. 1982. A comparative analysis of soil fauna populations and their role in decomposition processes. Oikos 39:287-388

80. Philip, J. R., DeVries, D. A. 1957. Moisture movement in porous materials under temperature gradients. Trans. Am. Geophys. Un. 38:222-28

81. Poinar, G. O. Jr., Hom, A. 1986. Survival and horizontal movement of infective stage Neoaplectana carpocapsae in the field. J. Nematol. 18:34-36

82. Rosenthal, G. A., Janzen, D. H., eds. 1979. Herbivores: Their interaction with Secondary Plant Metabolites. New York: Academic. 718 pp.

83. Ryan, M. F., Guerin, P. M. 1982. Behavioral responses of the carrot fly larva, Psila rosae, to carrot root volatiles. Physiol. Entomol. 7:315-24

84. Ryan, M. F., Gurein, P. M., Behan, M. 1978. Possible roles for naturally occurring chemicals in the biological control of carrot fly. In Proceedings of Symposium on Biological Control, ed. J. J. Duggan, pp. 130-43. Dublin: Royal Irish Acad., Irish Nat. Com. Biol.

85. Schroeder, W. J., Beavers, J. B. 1987. Movement of the entomogenous nematodes of the families Heterorhabditidae and Steinernematidae in the soil. J. Nematol. 19:257-59

86. Scott, G. C. 1974. The response of wheat bulb fly larvae to cereal exudates and extracts. Ann. Appl. Biol. 77:107-11

87. Seastedt, T. R. 1984. The role of microarthropods in decomposition and mineralization processes. Annu. Rev. Entomol. 29:25-46

88. Shriek, F. H. 1936. Plowing as a means of destroying wireworm pupae in the Pacific Northwest. U.S.D.A. Circular No. 407. 27 pp. Washington, DC

89. Soni, S. K., Finch, S. 1979. Laboratory evaluation of sulfur-bearing chemicals as attractants for larvae of the onion fly, Delia antiqua (Meigan) (Diptera: Anthomyiidae). Bull. Entomol. Res. 69:291-98

90. Stadler, E. 1971. Uber die Orientierung und das Wirtswahlverhalten der Mohrenfliege, Psila rosae F. I. Larven. Z. Angew. Entomol. 69:425-38

91. Stokes, B. M. 1956. A chemotactic response in wheat bulb fly larvae. Nature 178:801

92. Storey, G. K., Gardner, W. A. 1986. Soil profiles of applied aqueous suspensions of commercially-formulated Beauveria bassiana. In Fundamental and Applied Aspects of Invertebrate Pathology, ed. R. A. Samson, J. M. Vlak, D. Peters, p. 257. Wageningen, The Netherlands

93. Storey, G. K., Gamer, W. A. 1987. Vertical movement of commercially formulated Beauveria bassiana conidia through four Georgia soil types. Environ. Entomol. 16:178--81

94. Storey, G. K., Gardner, W. A. 1988. Movement of an aqueous spray of Beauveria bassiana into the profile of four Georgia soils. Environ. Entomol. $17: 135-39$

95. Strnad, S. P., Bergman, M. K. 1987. Movement of first-instar western corn rootworms (Coleoptera: Chrysomelidae) in soil. Environ. Entomol. 16:975-78

96. Strnad, S. P., Bergman, M. K., Fulton, W. C. 1986. First-instar western corn rootworms (Coleoptera: Chrysomelidae) response to carbon dioxide. Environ. Entomol. 15:839-42 
97. Sutherland, O. R. W. 1972. Olfactory responses of Costelytra zealandica (Coleoptera: Melolonthinae) larvae to grass root odours. N. Z. J. Sci. 15:165-72

98. Tashiro, H. 1987. Turfgrass Insects of the United States and Canada. Ithaca, NY: Cornell Univ. $474 \mathrm{pp}$.

99. Tashiro, H., Kuhr, R. J. 1978. Some factors influencing the toxicity of soil applications of chlorpyrifos and diasinon to European chafer grubs. J. Econ. Entomol. 71:904-07

100. Thorpe, W. H. Crombie, A. C., Hill, R., Darrah, J. H. 1947. The behavior of wireworms in response to chemical stimulation. J. Exp. Biol. 23:234-66

101. Villani, M. G., Gould, F. 1985. Butterfly milkweed as a feeding deterrent of the wireworm, Melanotus communis. Entomol. Exp. Applic. 37:69-75

102. Villani, M. G., Gould, F. 1985. Screening of crude plant extracts as feeding deterrents of the wireworm, Melanotus communis. Entomol. Exp. Applic. 37:95-100

103. Villani, M. G., Gould, F. 1986. Use of radiographs for movement analysis of the corn wireworm, Melanotus communis (Coleoptera: Elateridae). Environ. Entomol. 15:462-64

104. Villani, M. G., Meinke, L. J., Gould, F. 1985. Laboratory bioassay of crude extracts as antifeedants for the southern corn rootworm. Environ. Entomol. 14:617-19

105. Villani, M. G., Wright, R. J. 1988. Use of radiography in behavioral studies of turfgrass-infesting scarab grub species (Coleoptera: Scarabaeidae). Bull. Entomol. Soc. Am. 34:132-44

105a. Villani, M. G., Wright, R. J. 1990. Environmental considerations in soil insect pest management. In Handbook of Pest Management in Agriculture, Vol. 1, ed. D. Pimentel. Boca Raton, FL: CRC Press. 2nd ed.

106. Wallwork, J. A. 1959. The distribution and dynamics of some forest soil mites. Ecology 40:557-63

107. Wallwork, J. A. 1970. Ecology of Soil Animals. London: McGraw-Hill. 283 pp.

108. Wallwork, J. A. 1976. The Distribution and Diversity of Soil Fauna. London: Academic. 355 pp.

109. Wallwork, J. A. 1983. Oribatids in forest ecosystems. Annu. Rev. Entomol. 28: 109-30

110. Ward, R. H., Keaster, A. J. 1977. Wireworm baiting: Use of solar energy to enhance early detection of Melanotus deporessus and Aeolus mellilus in midwestern cornfields. J. Econ. Entomol. 70:403-6

111. Wellington, W. G. 1949. The synoptic approach to study of insects and climate. Annu. Rev. Entomol. 2:143-62

112. Wellington, W. G., Trimble, R. M. 1984. Weather. In Ecological Entomology, ed. C. B. Huffaker, R. L. Rabb, pp. 399-426. New York: Wiley. 844 pp.

113. Wetzel, R. G. 1975. Limnology, Philadelphia: W. B. Saunders. 743 pp.

114. Wright, R. J., Villani, M. G., Agudelo-Silva, F. 1988. Steinernematid and heterorhabditid nematodes for control of larval European chafers and Japanese beetles (Coleoptera: Scarabaeidae) in potted yews. J. Econ. Entomol. 81:152- 57

115. Zacharuk, R. Y. 1962. Distribution, habits and development of Ctenicera destructor in western Canada with notes on related species. Can. J. Zool. 49:539-52

116. Zacharuk, R. Y. 1963. Comparative preferences of soil, sand and wood inhabiting wireworms (Coleoptera-Elateridae). Can. J. Zool. 50:161-65 